\title{
The Effect of One Village One Product Movement on the Empowerment of Micro and Medium Enterprises (MSMEs)
}

\author{
Iman Fauzan Ary Tri Susilo Agus Utomo \\ Faculty of economics, Merdeka Ponorogo University, Indonesia
}

\begin{abstract}
The OVOP movement as a strategy in empowering the people's economy through the development of rural MSMEs. Each village with its unique characteristics can become a superior village product with high competitive potential, if there is a planned and sustainable coaching by the local and village governments. The synergy of the roles of local government and village government can strengthen the trust of village communities in prioritizing the development of village MSMEs.Through the development of rational business business management and operational technical support, it will be able to improve the quality of products that have high competitiveness to expand the marketing reach that is not limited to traditional markets but also modern markets. The development of village MSMEs - MSMEs will motivate village business actors to always develop creativity and innovation for the development of higher quality village business products, so as to increase village community income and encourage rural economic growth.
\end{abstract}

Keywords: OVOP, UMKM, Economic Empowerment

DOI: $10.7176 /$ RHSS/10-24-04

Publication date: December $31^{\text {st }} 2020$

\section{BACKGROUND}

Globalization has an impact on economic development in Southeast Asia, including in Indonesia, with the integration of the economy in Southeast Asia, which will result in a flood of foreign products entering the traditional and modern market systems. Various products ranging from food, clothing, pharmaceuticals, electronics, household products, and even agricultural products from various countries enter domestic markets. This does not only occur in traditional markets, but has even penetrated into digital trading systems (e-commerce), such as Bibli, one of the trading sites in Indonesia admits that of the 2.5 million products sold, only 50,000 to 100,000 products are local products (Ita Rakhmawati, 2019). For this reason, in anticipating this conditionality, it is necessary to grow and enhance the role of MSMEs to be able to compete and create products that can be accepted not only by domestic consumers but also consumers abroad, especially Southeast Asia. MSMEs are now one of the leading business sectors and as the main buffer capable of absorbing a lot of labor. Data from BPS and the Ministry of Cooperatives shows that most of the business class that is developing in Indonesia (99\%) are small-scale enterprises, and the remaining $1 \%$ are medium and large enterprises. This shows that the small business sector has an important role, especially in the absorption of labor, so that the small business sector becomes a force for small people to make ends meet. At least, there are 3 roles of MSMEs which are very important in the life of the small community. The three roles are: (1) Facilities to lift people out of poverty. The first important role of MSMEs is as a means of lifting small communities out of poverty. The main reason is the high rate of employment by MSMEs. This is evident in the data owned by the Ministry of Cooperatives and MSMEs in 2011. It is stated that more than 55.2 million MSMEs units are able to absorb around 101.7 million people. This figure has increased to around 57.8 million MSME units with a total workforce of 114 million people. (2) Means for leveling the economic level of the small people. MSMEs also have a very important role in the economic equality of society. Unlike large companies, MSMEs have locations in various places. Even in areas far from the reach of times. The existence of MSMEs in 34 provinces in Indonesia reduces the economic gap between the poor and the rich. In addition, small people do not need to go to the city in droves to get a decent living. (3) Provide foreign exchange income for the country. The next role of MSMEs that is no less important is to provide income for the country in the form of foreign exchange. Currently, Indonesian MSMEs are very advanced. Its market share is not only on a national scale, but internationally. Data from the Ministry of Cooperatives and SMEs in 2017 shows the high foreign exchange of MSMEs players. The figure is very high, reaching Rp. 88.45 billion. This figure has increased up to eight times compared to 2016 (Kompas, 2017).

Meanwhile, MSME products in Indonesia are still in the category of simple consumer goods, such as apparel, socks, goods made of wood, rattan, bamboo, and are even still oriented towards the domestic or regional market. This is different from MSME products produced by developed industrial countries, such as Taiwan, China, South Korea, Hong Kong and Singapore, which are dominated by consumer electronic goods and products for industrial purposes. By looking at the facts above, it is necessary to have government commitment in efforts to develop MSMEs with the target of developing superior commodities into national and global products. Through the Ministry of Health PDTT, the development of superior products is through the one village one product (OVOP) movement. This program aims to encourage the economic growth of rural communities. It is hoped that each 
village can find and develop a superior product that has different characteristics that are competitive in the domestic, national and global markets. Besides that, OVOP as an approach with efforts through the development of superior village products is also intended to increase the added value of superior village products in order to improve community welfare. The basic principle of OVOP is where the sub-district/village community is able to seek and explore commodities / products that can be superior in a sustainable manner and involve more members of the community, so that this movement is able to develop the potential of each village in an integrated manner to increase income and community welfare. while increasing self-confidence and pride in one's own abilities and the region. As an approach to development from within (endogenous development) that makes maximum use of the potential of the region as basic capital while maintaining environmental sustainability, people from an area can develop local wisdom and encourage the development of a "semi-secondary industry". This gives an understanding that society processes and provides added value to the primary products it produces (R Wijayanti). With the OVOP approach, it can grow and develop rural MSMEs as the people's economic base, so that they can become a means of increasing people's income and welfare.

\section{LITERATURE REVIEW}

\section{OVOP and Empowerment of MSMEs}

OVOP in implementing the concept of a people's economy is a strategy of empowering the people's economy, especially for small-scale economic actors. The people's economic system based on the 1945 Constitution is an economic system that emphasizes the aspect of democracy, meaning that the achievement of social welfare goals is carried out in a democratic way that prioritizes community involvement. The achievement of welfare is carried out through changes in the economic structure of the people which are felt to be less fair in the distribution of assets so that it affects people's productivity. In Bung Hatta's thinking, the interpretation of economic democracy is a people's economy, according to Zaenal Arifin Hoeseni (2016), in the explanation of article 33, Bung Hatta explains as follows: (1) Kinship is a cooperative. The principle of kinship is a term from Taman Siswa to show how teachers and students who do not consider it live as a family. That is what Indonesian cooperatives should have in common. (2) The meaning of being controlled by the State of the 1945 Constitution article 33 paragraph 2. The definition of being controlled by the state must be interpreted as covering the meaning of control by the state in a broad sense derived from and derived from the conception of the sovereignty of the Indonesian people over all sources of wealth "earth, water and natural resources contained therein ", includes the definition of public ownership by the collectivity of the people over the said wealth sources. The people collectively constructed by the 1945 Constitution mandate the state to establish policies (beleid) and management actions (bestuursdaad), regulation (regelendaad), management (behersdaad), and supervision (toezixhthoudensdaad) for the greatest possible benefit of the people. (3) The meaning is used for the greatest prosperity of the people contained in article 33 paragraph 3.The meaning of economic democracy contained in article 33 paragraph 4: Economic democracy according to Hatta (1932), as is Indonesian democracy, is rooted in the value of genuine democracy in the village. -villages in Indonesia. There are no elements of democracy in Indonesia: deliberation, freedom of opinion and help. By applying this pillar of economic democracy, there will no longer be a small number of people or groups who control the lives of many people just because they control the production factor as it is today. Ideally, the needs and wishes of many people should serve as guidelines for companies and income, therefore all production branches that provide large income and for the livelihoods of many people must be jointly managed under the care of the people with their representative bodies (sc.syekhnurjati.ac.id >researchmhs> BAB21413223073).

The people's economy is part of an effort to anticipate negative impacts due to the presence of market mechanisms that have the potential to open up opportunities for prolectarians who are easily exploitative. With a populist economy emphasizing equal distribution of business opportunities by involving wider community participation in various fields, both in the social, economic and political fields. According to Suhrawadi K Lubis \& Farid Wajdi (2012: 13), there are several principles in the populist economy, including: (1) Development strategy that takes the side of the people, (2) The principle of development guidelines based on deliberation and consensus, (3) Principle of integrated mechanisms development between the interests of local communities and national interests, (4) Principles of coordination across sectors and regions, and (5) Principles of preservation of development carried out through processes of development financing, monitoring and evaluation carried out by the people (sc.syekhnurjati.ac .id >researchmhs> BAB21413223073).

In real terms, the people's economy is intended to inspire competent parties, especially the government to think more about the economic fate of the small community, through its policies it is hoped that more pro-people's economies will be able to do better in order to improve their standard of living and at the same time reduce the occurrence of social inequality between communities. Thus, the people's economy prioritizes economic equality which is based on democracy, through real economic development to improve people's welfare and achieve economic justice. The concept of community economic development is translated into operational programs based on the economy of villages / wards, sub-districts, districts and cities with a high level of independence. However, it needs to be underlined that the development of the people's economy is translated into a regionalization 
perspective in which a unity of potential, advantages, opportunities, and socio-cultural character is integrated. The manifestation of this populist economy is the birth of activities of MSMEs and cooperatives as pillars of national economic development. Strengthening these pillars is certainly a necessity for the achievement of the basic objectives of the principle of a people's economy. And the concept of One Village One Product (OVOP) can be a policy in strengthening this pillar of the people's economy.

One Village One Product (OVOP) was originally pioneered by Morihiko Hiramatsu who was then the Governor of Oita, Japan to be precise in 1979. Initially, OVOP was a movement to build an area based on superior products. According to Yamazaki (2010), there are 3 main principles that underlie empowerment activities in OVOP. First, Local yet Global, is the underlying principle in developing OVOP products, where the products created must not only reflect local cultural pride but also be accepted globally by the international community. That way, the market for this product can be developed not only at the local or national level, but also internationally. Second, Self-reliance and creativity, through this principle, this movement also wants to emphasize the independence of local actors in managing their product businesses. This means that local residents actively manage their business independently, while the government only plays a role in providing the assistance needed for them to develop their business. Third, human resource development, must also be developed by local actors who manage this movement, not only independence. According to Hiramatsu, this human resource development can be achieved in the process of developing OVOP products, but on the other hand quality OVOP products can only be produced by qualified human resources who are committed to contributing to their local communities (id.wikipedia.org swiki>Movement_Satu_Desa_Satu_...).

In implementing the One Village One Product (OVOP) approach, cooperation is needed from three elements of development, namely government, businessmen, and intellectuals or often in the term "Triple helix". This Triple Helix concept, in implementing One Village One Product (OVOP) is a stakeholder element that includes all sectors and has mutually supporting relationships in implementing OVOP. As the term "triple helix", in developing OVOP, it requires the roles of three parties, namely the government, private sector and intellectuals who are obliged to support small and medium enterprises (SMEs). Every potential possessed by SMEs is facilitated by the government, encouraged by business and entrepreneurship by the private sector and a better mechanism is created in producing and improving product quality by intellectuals so that Indonesian local products can be better known, trusted and chosen by the community (Ayip, 2008). On an ongoing basis, the triple helix role is needed to support the development of these MSMEs. From MSMEs themselves, in order to continue to exist and be able to increase the competitiveness of their products in national and international market trade, MSMEs need to have networks with fellow MSMEs who are clustered according to their fields of movement and continue to have positive interactions. The role of the triple helix includes: (1). The role of the Central Government is here as a policy maker in implementing the One Village Product (OVOP) concept, because the central government through regulations must be able to accommodate the interests of each region in order to strengthen regional economic development. (2). The role of the Regional Government (Regency / City) is intended to develop the potential for superior local products. Each region needs to identify local superior products that may have the potential for competitiveness to be developed in entering modern markets. Technical guidance and support is expected to increase the capacity and quality of local superior products, so that they can be potential in increasing local economic growth. (3). The role of the private sector as a party that provides assistance in developing MSMEs - MSMEs products that are regional superior, through capital assistance and distribution of local superior products, it will be easier to expand the marketing network both regionally, nationally and globally. (4). The role of intellectuals is intended so that local superior products have sustainability and sustainability, so their main guidance is needed in the field of entrepreneurship. By holding MSME potential trainings and conducting research related to the development of the local product sector in order to innovate and compete in the global market.

\section{OVOP Implementation in Village Leading Products.}

One of the flagship programs that are being developed by the government through the Ministry of Health PDTT is the one village one product program. This program aims to encourage the economic growth of rural communities. Each village is encouraged to find and develop a superior product that has different characteristics from products from other villages. In the OVOP concept, the public is given an understanding to be able to produce selected goods with high added value. One village is expected to be able to produce a competitive main product and be able to compete at the global level but still have the unique characteristics of the region. The resulting products are products that utilize local resources, both natural and human resources.

The One Village One Product movement is an effort to foster the spirit of the village community to be involved in determining existing village products to be developed into superior village products. There is a lot of potential generated by villagers, but they have not received serious touch and treatment from the government so that the products produced in the village are not able to reach a wider market. For example, agricultural products of community members that produce durian fruit that are unique to other durians. Due to limited capabilities and social networks, the durian fruit produced by villagers should be initiated in such a way as to reach modern markets. 
For this reason, government commitment is needed in providing guidance to superior village products so that they have wider marketing access, so as to increase income and community welfare. The development of the OVOP program should not provide direct assistance to business actors, but what is more needed is their ability to better manage the business. Business activities developed by rural communities, usually as business activities passed down from generation to generation as a legacy from their families or can be said to be a continuation of business continuity that has been occupied by their parents, for example making tempe products, cassava tape, tofu, krupuk fulli, and various rural snacks. These rural business activities are usually only side businesses, which take advantage of the free time after the management of the agricultural sector so that the quantity and quality of the products produced are relatively limited and the marketing reach is very narrow or limited in their environment.

The business activities of the villagers actually become potential if they are developed in such a way that they can become various types of processed products that can be packaged in a modern way. Therefore, the OVOP approach is not only implemented in products that have a global orientation, but should also be applied to village products with an orientation towards regional or national marketing. This is of course very useful in anticipating various similar products from outside entering the regional market, because products from outside have entered at the district, sub-district, and even rural levels. The OVOP movement in the perspective of village products is intended to empower village superior products by adjusting OVOP principles in order to increase the competitiveness of village products at the regional and or national levels. The principles of OVOP in implementing village products include: (1) Local yet Regional / National, which is the underlying principle in developing OVOP products, where village products not only reflect village pride but also can be accepted in regional and national markets in particular. (2) Self-reliance and creativity, through this principle the development of village products as part of encouraging the independent movement of community members in managing their village product businesses. Emphasis on this principle fosters the independence of community businesses, and the government only plays a role in facilitating the needs of community members to develop their businesses. (3) Human resource development, is intended as an effort to improve business management so as to be able to produce quality village products and have more competitive competitiveness in order to enter modern markets. By adjusting the above principles, a wider range of business products will be possible to be developed and even each village can have at least one product as the village's superior product. Through more massive coaching, it is hoped that it can grow the village economy as well as an effort to increase the income and welfare of the community.

From the above points of thought, it can be stated as a hypothesis in this study, are:

1. Ho $=$ There is no influence between the One Village One Product movement on the empowerment of Micro, Small and Medium Enterprises,

2. $\mathrm{Ha}=$ There is an influence between the One Village One Product movement on the empowerment of Micro, Small and Medium Enterprises.

While the focus and direction of this research can be described in the following diagram:

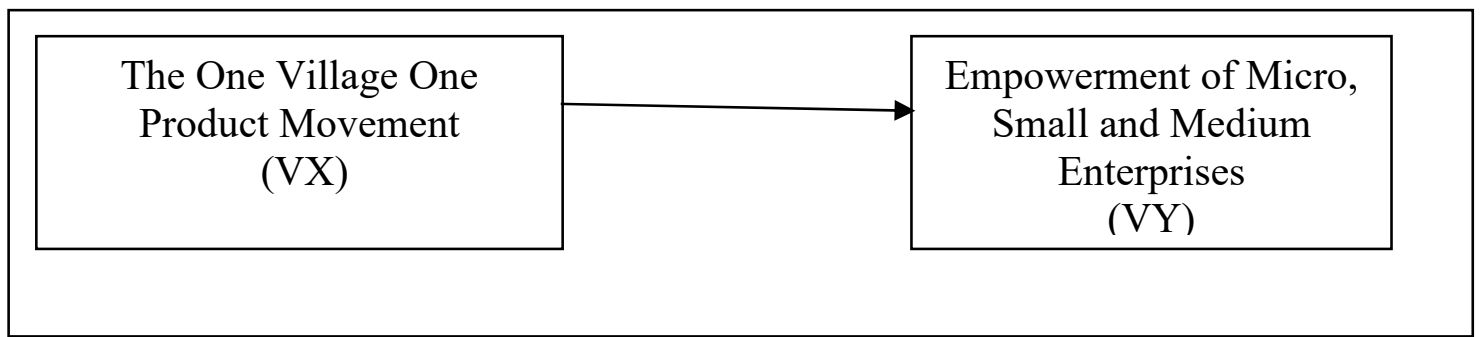

\section{RESEARCH METHODS.}

This research was conducted with a quantitative approach to analyze the influence of the One Village One Product Movement on the empowerment of Micro, Small and Medium Enterprises. Data were obtained through questionnaires to 120 respondents who were randomly selected in 6 villages in Ngawi Regency. Each village was determined by 20 respondents using stratified random sampling, consisting of: village government, and village MSMEs / village business actors. The respondent's assessment is measured using a Likert scale with a gradation from very positive to very negative, in the form of words including: a) Strongly agree with a score of 5, b) agree with a score of $4, \mathrm{c}$ ) Doubtful with a score of $3, \mathrm{~d}$ ) No agree with a score of 2, and e) Strongly disagree with a score of 1 . While the data analysis method uses a regression analysis model with processing through SPSS.

\section{RESULTS AND DISCUSSION.}

\section{Correlation Test}

To test the hypothesis, a correlation test was carried out between the One Village One Product (VX) Movement variable as the independent variable on the empowerment of Micro, Small and Medium Enterprises (VY) as the 
dependent variable. The results of the correlation test are as follows:

Table. 1

One Village One Product Movement Relationship towards Empowerment of Micro, Small and Medium Enterprises

Correlations

\begin{tabular}{|lll|r|r|}
\hline & & ProOVOP & PembUMKM \\
\hline Kendall's tau_b & ProOVOP & Correlation Coefficient & 1.000 & $.760^{* *}$ \\
& & & .000 \\
& & Sig. (2-tailed) & 120 & 120 \\
& $\mathrm{~N}$ & $.760^{* *}$ & 1.000 \\
& PembUMKM & Correlation Coefficient & .000 & 120 \\
& Sig. (2-tailed) & 120 & 120 \\
& $\mathrm{~N}$ & &
\end{tabular}

**. Correlation is significant at the 0.01 level (2-tailed).

From the table above, the correlation value between the one village one product movement variable and the empowerment variable for Micro, Small and Medium Enterprises is 0.760 with a $p$-value $=0.000$. When compared with the value $\alpha=0.05$, it is known that the p-value $=(0.000)<\alpha(0.05)$. Thus, the hypothesis Ha is accepted, namely that there is a correlation between the one village one product movement with the empowerment of Micro, Small and Medium Enterprises.

\section{Regression Test}

The results of the regression calculation between the OVOP strategy variables on the empowerment of Micro, Small and Medium Enterprises are:

Table. 2

The Influence of the One Village One Product Movement

Coefficients $^{\mathrm{a}}$ towards Empowerment of Micro, Small and Medium Enterprises

\begin{tabular}{|c|c|c|c|c|c|c|}
\hline \multirow{2}{*}{\multicolumn{2}{|c|}{ Model }} & \multicolumn{2}{|c|}{ Unstandardized Coefficients } & $\begin{array}{l}\text { Standardized } \\
\text { Coefficients }\end{array}$ & \multirow[b]{2}{*}{$\mathrm{t}$} & \multirow[b]{2}{*}{ Sig. } \\
\hline & & B & Std. Error & Beta & & \\
\hline & (Constant) & 3.295 & 3.250 & & 1.322 & .223 \\
\hline & ProOVOP & .871 & .055 & .812 & 14.252 & .000 \\
\hline
\end{tabular}

a. Dependent Variable: PembUMKM

From the regression equation $(\mathrm{Y}=\mathrm{a}+\mathrm{bX})$, it can be identified: (1) The constant value is 3.295 ; shows that the One Village One Product Movement will be constant if the empowerment variable for Micro, Small and Medium Enterprises is zero (none), assuming other factors remain or do not change in value. (2) The One Village One Product Movement variable which is valued at 0.871 (positive) indicates the influence of the One Village One Product Movement on the empowerment of Micro, Small and Medium Enterprises. If the One Village One Product Movement increases by 1 unit, the empowerment of Micro, Small and Medium Enterprises will also increase by 0.871. Thus the One Village One Product Movement has a positive effect on the empowerment of Micro, Small and Medium Enterprises.

\section{Determination Test.}

The coefficient of determination (R2) is used to measure how far the model's ability to explain variations in the dependent variable (Ghozali, 2006). The results of the determination coefficient test are:

Table 3

Results of the Determination Test between the One Village One Product Movement variables and empowerment of Micro, Small and Medium Enterprises

\section{Model Summary}

\begin{tabular}{|l|r|r|r|r|}
\hline Model & \multicolumn{1}{|c|}{$\mathrm{R}$} & R Square & Adjusted R Square & Std. Error of the Estimate \\
\hline 1 & & $.871^{\mathrm{a}}$ & .759 & 4.558 \\
\hline
\end{tabular}


The amount of Multiple Coefficient of Determination (R Square) is 0.759 or $75.9 \%$ which means that the empowerment of Micro, Small and Medium Enterprises can be explained by the One Village One Product Movement variable, while the remaining $24.1 \%$ is explained by other variables not explained in this research. The one-village one product movement is a program of the Ministry of Health and Technology, which aims to increase the income of villagers and simultaneously drive rural economic growth. The one village one product program is required for each village to have superior products that are possible to be developed widely through touches of product modernization, which can have broader marketing opportunities and potential reach. The success of empowering village MSMEs through the one village one product program is due to the support of local and village governments, through guidance carried out by the local government on an ongoing basis to improve the quality and quantity of superior village products that have potential for competitiveness in their marketing reach, not only limited to the market traditional but also modern markets. In addition, the support of the village government in synergizing the use of village funds can provide a stimulus for business capital for the development of village MSMEs. With the participation of the community, especially village business actors, can grow and motivate to develop superior village products so that they can increase community income and welfare.

\section{CONCLUSION.}

From the results of research conducted related to the OVOP program and empowerment of Micro, Small and Medium Enterprises, the following conclusions can be drawn:

1. The OVOP movement as a strategy in empowering the people's economy through the development of rural MSMEs can increase the competitiveness of products that have the potential to enter modern markets.

2. The success of the OVOP program cannot be separated from the synergy of the roles of local and village governments in providing facilities and technical support which can motivate village business actors to develop into superior village products of higher quality.

3. Commitment from the village government through synergy in the use of village funds can foster the trust of villagers in developing the business they have been engaged in.

4. With the village UMKM institution it can motivate village business actors to always develop creativity and innovation for the development of higher quality business products, so that they are able to compete not only in traditional markets but also in modern markets.

5. The development of village business actors can increase the income of rural communities and simultaneously support rural economic growth.

\section{REFERENCES}

Ghozali, Imam, 2006, Aplikasi Analisis Multivariate Dengan Program SPSS, Semarang: Badan Penerbit Universitas Diponegoro.

Ita Rakhmawati, 2019,

Pemberdayaan UMKM Berbasis “One Village One ... E-ISSN: 2477-5533. Volume 7, Nomor 1, Juni 2019 ... Bandung: Pustaka Setia. Kementerian ..., www.researchgate.net > publication,

Kompas, 2017, https:/www.kompasiana.com/hikhman/599eabfae728e442d60622e2/3-peran-penting-umkmpenggerak-penting-ekonomi-indonesia

R Wijayanti, Pengertian Ekonomi Kreatif - Contoh, Ciri, Manfaat Dan ..., www.dosenpendidikan.co.id , pengertian-ekonomi-...

Zaenal Arifin Hoeseni, "Peran Negara Dalam Pengembangan Sistem Ekonomi Kerakyatan Menurut UUD 1945", Jurnal Hukum IUS QUIA IUSTUM 3:23 (Juli 2016):513

.....................BAB II EKONOMI KERAKYATAN Sebelum membahas detail ..., sc.syekhnurjati.ac.id > risetmhs , BAB21413223073

id.wikipedia.org > wiki > Gerakan_Satu_Desa_Satu_... 